\title{
Drivers of plant species composition in siliceous spring ecosystems: groundwater chemistry, catchment traits or spatial factors?
}

\author{
Michael STROHBACH ${ }^{1,2)}$, Volker AUDORFF ${ }^{1) *}$ and Carl BEIERKUHNLEIN ${ }^{1)}$ \\ ${ }^{1)}$ University of Bayreuth, Bayreuth Center of Ecology and Environmental Research BayCEER, Department of Biogeography, \\ Universitätsstraße 30, 95440 Bayreuth, Germany \\ ${ }^{2)}$ UFZ - Helmholtz Centre for Environmental Research, Computational Landscape Ecology, Permoserstraße 15, 04318 Leipzig, \\ Germany \\ *e-mail corresponding author: volker.audorff@uni-bayreuth.de
}

\section{ABSTRACT}

Spring water reflects the hydrochemistry of the aquifer in the associated catchments. On dense siliceous bedrock, the nearsurface groundwater flow is expected to be closely related to the biogeochemical processes of forest ecosystems, where the impact of land use is also low. We hypothesize that the plant species composition of springs mainly reflects hydrochemical conditions. Therefore, springs may serve as indicator systems for biogeochemical processes in complex forest ecosystems. To test this hypothesis, we investigate the influence of spring water chemical properties, catchment traits, and spatial position on plant species composition for 73 springs in forested catchments in central Germany, using non-metric multidimensional scaling (NMDS), Mantel tests, and path analyses. Partial Mantel tests and path analyses reveal that vegetation is more greatly influenced by spring water chemistry than by catchment traits. Consequently, the catchment's influence on vegetation is effective in an indirect way, via spring water. When considering spatial aspects (in particular altitude) in addition, the explanatory power of catchment traits for spring water properties is reduced almost to zero. As vegetation shows the highest correlation with the acidity gradient, we assume that altitude acts as a sum parameter that incorporates various acidifying processes in the catchment. These processes are particularly related to altitude - through bedrock, climatic parameters and forest vegetation. The species composition of undisturbed springs is very sensitive in reflecting such conditions and may serve as an integrative tool for detecting complex ecological processes.

Key words: acidification, catchment biogeochemistry, landscape traits, partial Mantel test, path analysis, spring water

\section{INTRODUCTION}

Springs are remarkably different from other habitats. Odum (1971) summarized this fact when he wrote:

"Springs are the aquatic ecologist's natural constant temperature laboratory. Because of the relative constancy of the chemical composition, velocity of water, and temperature, in comparison with lakes, rivers, marine environments, and terrestrial communities, springs hold a position of importance as study areas that is out of proportion to their size and number".

Most ecosystems of temperate Central Europe are strongly influenced, controlled or even determined by direct human impact such as intensive land use and frequent disturbances related to mobility and urbanization. Communities with low turnover rates that are dominated by natural drivers of ecosystem functioning are rarely found.

The subject of this study, springs in forest areas, represents an exception to the predominantly anthropogenic ecosystems of Europe. Land use options are negligible as a consequence of the permanently saturated moisture regime. In addition, human interest is low due to the small extent of spring sites. Warncke (1980) refers to them as islands in an ocean of cultivated land.
In forested catchments in particular, they can be regarded as low dynamic semi-terrestrial ecosystems that reflect long-term ecological processes and the biogeochemical background of landscape compartments. On dense siliceous bedrock, water is transported mainly as interflow close to the surface in Pleistocene layers of solifluction (Kleber et al. 1998). In these landscapes, springs generally develop as helocrenic springs - a saturated mire of small extent (with a mean of approx. 50 to $100 \mathrm{~m}^{2}$ ) where water seeps out more or less continuously from the ground. Discharge rates are usually low $\left(<2.0 \mathrm{~L} \mathrm{~s}^{-1}\right)$. Depending on the climate and the size of the catchment area, seasonal fluctuations are reflected by a certain variability of discharge. Water temperature, and therefore also surface-near air temperature, is equilibrated in these springs by the permanent energy supply by groundwater. Due to their ecological constancy (as addressed by Odum 1971), springs provide a habitat for stenoecious species that cannot be found in the surrounding ecosystems. Despite their small size Heino et al. (2005) regard them as "key biotopes" because springs enhance the biodiversity of the terrestrial landscape.

The following aspects of Central European siliceous, helocrenic forest springs, make them an interesting subject of research: (1) They are small in size but the water quantity and quality reflects hydrological and 
biogeochemical processes of a much larger catchment area (Beierkuhnlein \& Durka 1993). Springs act as a point-shaped outlet of complex, black-box-like ecosystems. (2) The area of seeping spring water is clearly differentiated from the surrounding habitats by surface morphology. This well-defined boundary is a consequence of frost heaving of substrate and vegetation during freeze-thawing cycles in winter and makes it easy to assess whether species are dwelling in the spring itself or the neighbouring terrestrial habitats. Their clear delimitation renders springs appropriate tools to measure biogeochemical fluxes. (3) Organisms living in the springs are strongly related to the quality and quantity of outpouring groundwater. Thus, they are adapted to relative environmental constancy (Thienemann 1924; Odum 1971), which qualifies them as bio-indicators of overall and mean environmental properties (Cantonati et al. 2006). (4) In spite of the fact that springs make up only a small proportion of the land surface, they are rather abundant in the vast forested mountain ranges of Central Europe. This high frequency is a prerequisite for investigations at the landscape scale because it provides data with a high spatial resolution (Beierkuhnlein \& Durka 1993; Beierkuhnlein 1996).

Spring water reflects the properties of the percolated volume that makes up their catchment and of the processes that occur there, or as Church (1997) puts it: "Where water goes in a forested catchment, how long it lingers, what materials and organisms it encounters on its journey - all interact to determine its character". The "small catchment approach" (e.g., Moldan \& Černý 1994; Church 1997; Likens \& Bormann 1999) applies to siliceous springs.

Over recent decades acid deposition has been a severe environmental problem in forested catchments of the northern hemisphere, accompanied by damage to and the decline of forest vegetation as well as by the alteration of soils, ground-, spring- and headwaters. Even though acid depositions in Central Europe have gone down considerably since the early 1990s, the recovery of catchments seems to be delayed (Alewell et al. 2001). Acidification remains an important environmental issue. The link between acid depositions and ecosystem damage is modified by the buffering capacity of the soils in the catchment (Probst et al. 1999; Williard et al. 2005), but also dependent on factors that alter the deposition load of the catchment like the surface roughness of vegetation (e.g., deciduous or coniferous forest) (Williard et al. 2005) or the altitude, slope and orientation of the catchment (Palmer et al. 2004; Rantakari et al. 2004).

In contrast with other communities, the species composition of springs and fens is congeneric over wide areas of the northern hemisphere. Species occurrence and composition are assumed to be controlled substantially by the gradients of nutrient occurrence and nutrient availability (i.e. acidity) (Vitt \& Chee 1990; Hájek et al. 2002; Nekola 2004; Tahvanainen 2004). In the springs of Central Europe, the water $\mathrm{pH}$-value has been shown to be the most important explanatory variable (Beierkuhnlein \& Gräsle 1998; Hájková et al. 2008). Hence, crenobiotic plant species have been proposed as indicators for monitoring acidification (Beierkuhnlein 1996). In order to take a closer look at the indicative power of the vegetation of springs, we studied how the three compartments - catchment properties, spring water chemistry and vegetation - are interrelated. We hypothesize that plant species composition mainly reflects hydrochemical conditions. Additionally we tested the datasets for spatial dependencies. The objective of this study was to reveal paths and the magnitude of the impact of the catchment's traits on plant species composition in springs.

\section{METHODS}

\subsection{Sites and study area}

We investigated springs and their catchments, located in the Frankenwald and Fichtelgebirge mountain ranges, in the center of Germany $\left(49.9^{\circ}-50.6^{\circ} \mathrm{N}, 11.2^{\circ}\right.$ $-12.2^{\circ} \mathrm{E}$; see Fig. 1). These landscapes cover an area of roughly $900 \mathrm{~km}^{2}$ each, ranging in altitude from 350 to $1050 \mathrm{~m}$ a.s.l. Bedrock material consists of palaeozoic silicate rocks - schist, phyllite, greywacke, gneiss and granite. Long-term mean annual air temperatures vary between 5 and $7{ }^{\circ} \mathrm{C}$ with annual precipitation between 750 and $1200 \mathrm{~mm}$. All investigated springs $(\mathrm{n}=73)$ and their catchments are located in state-owned forests that are dominated by Norway spruce (Picea abies [L.] H. Karst) The altitude of the spring sites ranges from 388 to $909 \mathrm{~m}$ a.s.l., and their catchment area varies between 800 and $200,000 \mathrm{~m}^{2}$. The $\mathrm{pH}$-value of the nutrient-poor spring water is acidic to neutral (annual mean between 3.86 and 7.33), and electrical conductivity ranges from 27 to $892 \mu \mathrm{S} \mathrm{cm}^{-1}$ (annual mean). Their vegetation belongs to the associations Chrysosplenietum oppositifolii Oberdorfer \& Philippi 1977, Caricetum fuscae polytrichetosum communis Oberdorfer 1938 or transition types between these (following the classification of Hinterlang 1992).

\subsection{Data collection}

The abundance/dominance score of each vascular plant, moss and liverwort species growing in the welldifferentiated saturated area of the helocrenic spring was estimated once in the summer of 2003. In total 220 plant species were recorded with an average of 31 species per spring (minimum 10, maximum 69).

Spring water was sampled 10 times from September 2003 to August 2004 at regular intervals, and always at the uppermost point of the saturated area with aboveground flowing water. Electrical conductivity, $\mathrm{pH}$-value and acid neutralizing capacity were measured in situ. For every recording water samples were taken and ana- 


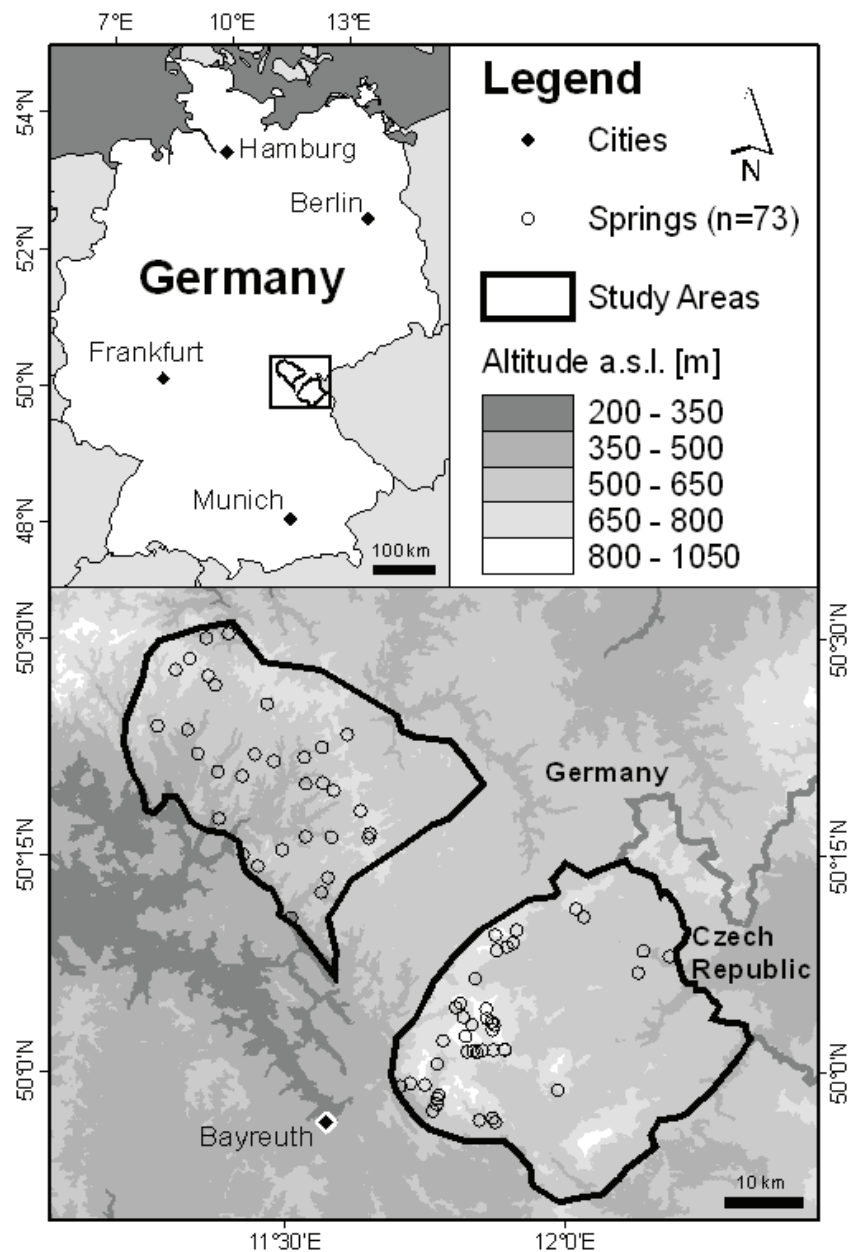

Fig. 1. Location of the 73 springs investigated in Central Germany.

lyzed for the dissolved concentrations of $\mathrm{DOC}, \mathrm{NO}_{3}{ }^{-}$, $\mathrm{SO}_{4}^{2-}, \mathrm{Ca}, \mathrm{Mg}, \mathrm{K}, \mathrm{Fe}, \mathrm{Mg}, \mathrm{Al}, \mathrm{Zn}, \mathrm{Cu}, \mathrm{Ni}, \mathrm{Cd}, \mathrm{Na}, \mathrm{Cl}$, dissolved $\mathrm{N}$, dissolved $\mathrm{S}$ and $\mathrm{Si}$. We included the annual mean, maximum and minimum of all measured parameters. As it can be expected that the extreme values of e.g. $\mathrm{pH}$-value or $\mathrm{Al}^{3+}$ might not be tolerated by some species, the extreme values could be more important for the formation of plant communities in springs than the average values. The extreme values and the mean values led to 63 variables derived from 21 spring water parameters.

A digital elevation model (DEM) of the area was created by interpolation of the vectorized contour lines of the digital topographic map $(1: 25,000)$ using the ESRI ArcGIS 3D Analyst and the Nearest Neighbor algorithm. Based on the DEM, the aboveground catchment for each given pour point was calculated (using ESRI ArcGIS Spatial Analyst 8.2). At the landscape scale springs appear as a point. To cope with spatial inexactness in location and extension, a buffer was applied around each pour point. This way a larger pouring area was simulated. In order to delineate the catchments for all springs in one step, an estimation of the best buffer radius had to be made. For a number of buffer sizes, the catchment was delineated to calculate the catchment areas. The latter, multiplied with the average winter precipitation (December to February, season with the least evapotranspiration), resulted in a parameter that equates to the potential winter spring water discharge. The correlation between measured winter spring water discharge and potential winter spring water discharge was highest $\left(r^{2}=0.22 ; p<0.001\right)$ for the catchments calculated with a buffer radius of 12 $\mathrm{m}$ around the pour point. The resulting catchment areas are ranging between 0.1 and 20.1 ha (2.9 ha in mean).

Subsequently landscape traits were sampled using GIS (ESRI ArcGiS 8.2) by intersecting different information layers with the catchment areas. Additionally the tree cover above the spring was included in this set of data to represent light availability. For practical reasons and to make a clear distinction from the water chemistry (obtained from a point measurement in the spring), this information based on the catchment area (cf. Tab. 1) will simply be referred to as catchment data in the following. The 35 highly collinear climatic parameters that had been included were condensed, using a principal components analysis. The first three principal components, representing 55,10 and $7 \%$ of the total variance 
Tab. 1. An overview of data sources, parameters, data types and units of catchment data.

\begin{tabular}{|c|c|c|c|c|}
\hline Data & Source & Parameter description & Data type and unit & Number \\
\hline \multirow{3}{*}{$\begin{array}{l}\text { Forest management maps } \\
\text { scale } 1: 10000\end{array}$} & \multirow{3}{*}{$\begin{array}{l}\text { Bavarian State Forest } \\
\text { Administration }\end{array}$} & deciduous trees in forest stand & $\begin{array}{l}\text { proportion of catchment area covered by } \\
\text { deciduous trees [\%] }\end{array}$ & 1 \\
\hline & & 4 stand age classes & $\begin{array}{l}\text { proportion of catchment area covered by } \\
\text { class [\%] }\end{array}$ & 4 \\
\hline & & 6 usage classes & $\begin{array}{l}\text { proportion of catchment area covered by } \\
\text { class [\%] }\end{array}$ & 6 \\
\hline $\begin{array}{l}\text { Forest fertilization maps } \\
\text { scale } 1: 10000\end{array}$ & $\begin{array}{l}\text { Bavarian State Forest } \\
\text { Administration }\end{array}$ & $\begin{array}{l}\text { liming location and year ( } 3 \text { periods: years } \\
1980-1988 ; 1989-1996 ; 1997-2003 \text { ) }\end{array}$ & $\begin{array}{l}\text { proportion of catchment area limed in } \\
\text { time span }[\%]\end{array}$ & 3 \\
\hline \multirow{3}{*}{$\begin{array}{l}\text { Forest habitat / soil maps } \\
\text { scale } 1: 10000\end{array}$} & \multirow{3}{*}{$\begin{array}{l}\text { Bavarian State Forest } \\
\text { Administration }\end{array}$} & 5 substrate classes & $\begin{array}{l}\text { proportion of catchment area covered by } \\
\text { class [\%] }\end{array}$ & 5 \\
\hline & & 7 fertility classes & & 7 \\
\hline & & 8 water accessibility classes & $\begin{array}{l}\text { proportion of catchment area covered by } \\
\text { class }[\%]\end{array}$ & 8 \\
\hline $\begin{array}{l}\text { Climate maps } \\
\text { (years 1961-1990) } \\
\text { resolution } \\
400 \mathrm{~m} \times 400 \mathrm{~m}\end{array}$ & $\begin{array}{l}\text { Bavarian Climate } \\
\text { Research Council }\end{array}$ & $\begin{array}{l}\text { first } 3 \text { principal components of } 35 \text { climate } \\
\text { parameters (temperature, precipitation, } \\
\text { solar radiation, wind, fog and phenology) } \\
\text { that counts for the majority of the } \\
\text { catchment }\end{array}$ & $\begin{array}{l}\text { artificial parameters: principal } \\
\text { components (axis scores) [unitless] }\end{array}$ & 3 \\
\hline $\begin{array}{l}\text { Geological maps } \\
\text { scale 1:25000 }\end{array}$ & $\begin{array}{l}\text { Bavarian Environment } \\
\text { Agency }\end{array}$ & $\begin{array}{l}53 \text { geological units (classified into } 6 \\
\text { groups resembling mineral content) }\end{array}$ & $\begin{array}{l}\text { proportion of catchment area covered by } \\
\text { group [\%] }\end{array}$ & 6 \\
\hline \multirow{4}{*}{$\begin{array}{l}\text { Topographic maps } \\
\text { scale } 1: 25000\end{array}$} & \multirow{4}{*}{$\begin{array}{l}\text { Bavarian Office for } \\
\text { Surveying and } \\
\text { Geographic } \\
\text { Information }\end{array}$} & $\begin{array}{l}\text { flow length to spring (from contour lines } \\
\text { via DEM) }\end{array}$ & flow length $[\mathrm{m}]$ & 1 \\
\hline & & hill slope (from contour lines via DEM) & hill slope [degree] & 1 \\
\hline & & orientation (from contour lines via DEM) & $\begin{array}{l}\text { proportion of catchment area covered by } \\
\text { direction class }(\mathrm{N}, \mathrm{E}, \mathrm{S}, \mathrm{W})[\%]\end{array}$ & 4 \\
\hline & & $\begin{array}{l}\text { road in }<100 \mathrm{~m} \text { vicinity of catchment } \\
\text { catchment size (from DEM) }\end{array}$ & $\begin{array}{l}\text { presence / absence [unitless] } \\
\text { area }\left[\mathrm{m}^{2}\right]\end{array}$ & $\begin{array}{l}1 \\
1\end{array}$ \\
\hline Shading & own vegetation relevès & tree cover & $\begin{array}{l}\text { proportion of spring area covered by trees } \\
{[\%]}\end{array}$ & 1 \\
\hline \multicolumn{2}{|l|}{ Total } & & & 52 \\
\hline
\end{tabular}

of the climate parameters, were extracted and used as surrogate climatic parameters. The first principal component showed a high positive loading of all temperature parameters, and a negative loading of precipitation and number of foggy days. The radiation budget in the spring and summer displayed a negative loading and wind speed displayed a positive loading on the second principal component, while the main factor that loads the third principal component is radiation in October. The principal components analysis was calculated using the function prcomp from the stats package in $\mathrm{R}(\mathrm{R}$ Development Core Team 2007). In total the catchment data set consists of 52 parameters, which are presented in table 1 .

\subsection{Data transformation}

Vegetation data were homogenized by removing the abundances of all tree species (only juvenile trees were found, which can't survive in the saturated areas and are therefore not representative) and by omitting the abundances of species, which were found only in one single spring. Braun-Blanquet's abundance/dominance scores of the 126 remaining species were converted into a percentage cover. To down-weight species with high abundances, cover data were square-root transformed. Legendre \& Gallagher (2001) recommend up-weighting rare species when comparing communities to environmental data. Therefore the vegetation data was additionally submitted to wisconsin double standardization whereby species are standardized to maximum cover and samples to equal totals.

Water chemistry parameters were homogenized in order to resemble the $\mathrm{pH}$-value. At first the element and compound concentrations below the Limit of Quantitation (LOQ) were substituted by $0.5 \times$ LOQ. Then the common logarithm was calculated for all parameters except for the $\mathrm{pH}$-value which is the negative common logarithm of the hydronium concentration, but also excluding the acid neutralizing capacity which includes zero values. Instead, a square root transformation was chosen for the latter parameter.

\subsection{Data analysis}

The sampling process resulted in three different sets of data. Figure 2 shows the presumed model of the relationships between the variables. To compare the data, Mantel tests were carried out (Mantel 1967). We chose this method because it enables multivariate response variables, like community data, to be directly compared with environmental predictors similar to univariate regression and path analysis (Legendre \& Legendre 1998). Clarke \& Ainsworth (1993) proposed 
iterative Mantel tests to detect the subset of environmental parameters, which is best correlated with community data. The dissimilarity matrix of the plant community is correlated with the matrices that are obtained from all of the possible subsets of the environmental data and the subset with the best correlation is identified.

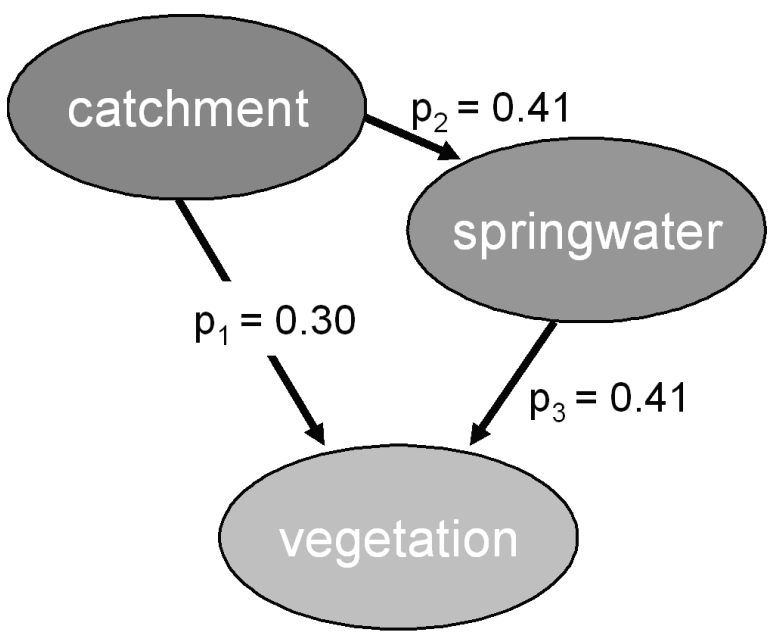

Fig. 2. Presumed relationships between the vegetation of springs, the spring water and the catchment. The path coefficients were calculated in a path analysis between the distance matrices of the three parameter sets.

Unfortunately, this method is still limited by computational power, with $\mathrm{n}$ parameters leading to $2^{(\mathrm{n}-1)}$ possibilities and 63 water chemistry parameters leading to $4.6 \times 10^{18}$ possibilities. Therefore a pre-selection of variables was carried out with the help of non-metric multidimensional scaling (NMDS). A two dimensional NMDS of the community data was calculated by means of the function metaMDS that is incorporated in the statistical package vegan in $\mathrm{R}$ (Oksanen et al. 2007).

The NMDS is based on a similarity matrix calculated from the vegetation data using the Bray-Curtis index. This similarity matrix will simply be referred to as vegetation matrix below. The environmental vectors with the maximum correlation with corresponding environmental variables were fitted on the NMDS ordination by the function envfit from the same package. These vectors indicate the direction of the ordination in which the variable changes most rapidly. On pre-selection only those variables with a significant correlation $(p<0.1)$ were accepted for further analysis, with significance being calculated in envfit using 1000 permutations. Out of the minimum, maximum and mean of each hydrochemical parameter only the one with the highest correlation was considered. In total 15 hydrochemical parameters (Tab. 2) and 20 catchment parameters were preselected (Tab. 3).

Based on these preselected variables iterative Mantel tests were calculated using the function bioenv, that is also included in the statistical package vegan in $\mathrm{R}$
(Oksanen et al. 2007), with the vegetation matrix, Euclidian distance matrices of the spring water and catchment data and Pearson's coefficient as a correlation measure. Finally, partial Mantel tests were calculated using the statistical package ecodist in R (Goslee \& Urban 2007) and path analyses were carried out. Partial Mantel tests enable the correlation of two dissimilarity matrices while controlling for the effect of others. They allow for a form of causal modelling (Legendre \& Legendre 1998), which is an advantage compared to variation partitioning.

Tab. 2. Preselected chemical parameters of the spring water. Preselection was carried out using the significance $(p<0.1)$ of environmental vectors fitted to an NMDS ordination of the vegetation data. Those 3 parameters that constitute the spring water matrix are printed in bold characters.

\begin{tabular}{lcc}
\hline Parameter & $r^{2}$ & $p$ \\
\hline $\mathbf{p H}$ & $\mathbf{0 . 7 1 9}$ & $<\mathbf{0 . 0 0 1}$ \\
$\mathbf{A l}_{\text {avg }}$ & $\mathbf{0 . 6 6 3}$ & $<\mathbf{0 . 0 0 1}$ \\
$\mathbf{M g}$ avg & $\mathbf{0 . 5 9 9}$ & $<\mathbf{0 . 0 0 1}$ \\
$\mathrm{Mn}_{\text {min }}$ & 0.535 & $<0.001$ \\
$\mathrm{ANC}_{\text {avg }}$ & 0.511 & $<0.001$ \\
$\mathrm{Ca}_{\text {max }}$ & 0.481 & $<0.001$ \\
$\mathrm{Cd}_{\text {avg }}$ & 0.312 & $<0.001$ \\
$\mathrm{DOC}_{\text {avg }}$ & 0.199 & $<0.001$ \\
$\mathrm{Zn}_{\text {min }}$ & 0.162 & 0.003 \\
$\mathrm{NO}_{3 \text { min }}$ & 0.148 & 0.005 \\
$\mathrm{SO}_{4}$ min & 0.131 & 0.003 \\
$\mathrm{Fe}_{\text {min }}$ & 0.115 & 0.008 \\
$\mathrm{Ni}_{\text {avg }}$ & 0.111 & 0.009 \\
$\mathrm{Na}_{\text {max }}$ & 0.090 & 0.038 \\
$\mathrm{Cl}_{\text {max }}$ & 0.088 & 0.037 \\
\hline
\end{tabular}

Tab. 3. Preselected catchment parameters. Preselection was carried out using the significance $(p<0.1)$ of environmental vectors fitted to an NMDS ordination of the vegetation data. The 9 parameters that constitute the catchment matrix are printed in bold characters.

\begin{tabular}{lcc}
\hline Parameter & $r^{2}$ & $p$ \\
\hline Climate PRC1 & $\mathbf{0 . 6 5 0}$ & $<\mathbf{0 . 0 0 1}$ \\
Bedrock 6 (granite) & $\mathbf{0 . 4 0 4}$ & $<\mathbf{0 . 0 0 1}$ \\
Soil type 2 (loamy sand) & $\mathbf{0 . 3 3 1}$ & $<\mathbf{0 . 0 0 1}$ \\
Soil type 3 (loam) & 0.295 & $<0.001$ \\
Bedrock 2 (slate) & $\mathbf{0 . 2 7 1}$ & $<\mathbf{0 . 0 0 1}$ \\
Soil water 1 (dry) & $\mathbf{0 . 1 7 1}$ & $\mathbf{0 . 0 0 1}$ \\
Soil water 8 (wet) & 0.158 & 0.003 \\
Soil water 5 (moist) & 0.150 & 0.003 \\
Cover of deciduous trees & $\mathbf{0 . 1 4 0}$ & $\mathbf{0 . 0 0 6}$ \\
Soil fert. 6 (soil on slope) & 0.140 & 0.005 \\
Soil type 1 (sand) & 0.137 & 0.006 \\
Bedrock 5 (phyllite) & 0.135 & 0.005 \\
Tree cover & $\mathbf{0 . 1 2 9}$ & $\mathbf{0 . 0 0 6}$ \\
Avg. slope of catchment & $\mathbf{0 . 1 2 3}$ & $\mathbf{0 . 0 1 1}$ \\
Catchment facing west & 0.113 & 0.013 \\
Soil fert. 4 (rich in humus) & 0.111 & 0.004 \\
Soil fert. 2 (poor) & 0.097 & 0.036 \\
Climate PRC2 & 0.094 & 0.037 \\
Eastward orientation & $\mathbf{0 . 0 9 1}$ & $\mathbf{0 . 0 3 7}$ \\
Soil type 5 (bog and fen) & 0.086 & 0.046 \\
\hline
\end{tabular}


Path analysis works in a comparable way: path coefficients, which resemble standard partial regression coefficients, are calculated. Both methods give an insight into (statistical) relationships between collinear variables, or in our case collinear distance matrices. The application of path analyses on Mantel regression coefficients rather than regression coefficients was carried out according to Nantel \& Neumann (1992).

The results of the partial Mantel test pointed to an unmeasured parameter connected to catchment traits and spring water. That is why spatial parameters were included in the analysis. Space itself is not directly linked to ecological processes, but it can be used to represent factors and processes that are modified in space (Leduc et al. 1992). Horizontal and vertical geographical positions were analyzed respectively as additional parameters in the described Mantel tests, partial Mantel tests and path analyses (using Euclidian distance as the distance measure).

\section{RESULTS}

\subsection{Interrelation of catchment, spring water and species composition}

The highest correlation between the vegetation matrix and the catchment traits was found by the Mantel tests for a Euclidian distance matrix calculated using 9 parameters: $1^{\text {st }}$ principal component of the climate parameters, proportional area of deciduous trees, two bedrock parameters (weak metamorphous bedrock and granite), two soil parameters (loamy sand and dry soil), tree cover, slope and eastward orientation. This distance matrix will be referred to as the catchment matrix below.

The analogously highest correlation with the vegetation matrix was found for the Euclidian distance matrix containing the three spring water parameters: average $\mathrm{pH}$-value, average $\mathrm{Mg}$ and average Al. This distance matrix will be referred to as spring water matrix in the following.

The results of the Mantel tests between the vegetation matrix, spring water matrix and catchment matrix are shown in table 4 . The vegetation matrix was both significantly correlated $(p<0.001)$ with the spring water matrix $\left(r_{\mathrm{M}}=0.54\right)$ and the catchment matrix $\left(r_{\mathrm{M}}=0.47\right)$. The spring water matrix and the catchment matrix were also correlated $\left(r_{\mathrm{M}}=0.41\right.$, all $\left.p<0.001\right)$. This shows that the spring water and the catchments' characteristics could explain similar quantities of the variation in the vegetation data, but as they are also correlated with each other, no conclusion about their combined explanatory power could be drawn.

Partial Mantel tests decreased all correlations. This indicates that to a certain degree the correlation between the vegetation matrix and the catchment matrix as well as the correlation between the vegetation matrix and the spring water matrix was due to a spurious correlation. There was however no explanation for the strong decline in the correlation between the spring water matrix and the catchment matrix when controlling for the effect of the vegetation matrix $\left(r_{\mathrm{M}}=0.41\right.$ to $\left.r_{\mathrm{pM}}=0.21\right)$.

Tab. 4. Results (Pearson correlation) of Mantel tests ( $r_{\mathrm{M}}$, above diagonal) and partial Mantel tests ( $r_{\mathrm{pM}}$, below diagonal) between vegetation (VEG), spring water chemistry $\left(\mathrm{H}_{2} \mathrm{O}\right)$ and catchment traits $(\mathrm{CATCH})$. All correlations are significant $(p<0.001)$.

\begin{tabular}{lccc}
\hline & VEG & $\mathrm{H}_{2} \mathrm{O}$ & CATCH \\
\hline \multicolumn{4}{c}{ Mantel test $r_{\mathrm{M}}=$} \\
$\mathrm{VEG}$ & & 0.54 & 0.47 \\
$\mathrm{H}_{2} \mathrm{O}$ & 0.43 & 0.21 & 0.41 \\
$\mathrm{CATCH}$ & 0.32 & 0.21 & \\
& \multicolumn{3}{c}{ partial Mantel test $r_{\mathrm{pM}}=$} \\
\hline
\end{tabular}

The path analysis for the model shown in figure 2, with the catchment influencing both vegetation (path $p_{1}$ ) and water chemistry (path $p_{2}$ ) and the water chemistry influencing vegetation (path $p_{3}$ ), fortify the result of the partial Mantel tests. The resulting path coefficients were $p_{1}=0.30, p_{2}=0.41$ and $p_{3}=0.41$ (cf. Fig. 2). The total correlation between the catchment matrix and the vegetation matrix was $r_{\text {tot }}=0.47 .36 \%$ of this correlation was indirect, which means that the catchment attributes influence the vegetation by altering the spring water. The vegetation of the springs was more greatly influenced by the water chemistry than by the catchment parameters $\left(p_{3}>p_{1}\right) .23 \%$ of the correlation between the vegetation matrix and the spring water matrix was due to a spurious correlation. $64 \%$ of the variation in the vegetation matrix was not explained by the model.

\subsection{Influence of geographical position}

The correlation between the vegetation matrix and the horizontal distance was weak $\left(r_{\mathrm{M}}=0.14\right)$ and it ceased $\left(r_{\mathrm{pM}}=-0.02\right)$ when it was controlled for the catchment and spring water effects with partial Mantel tests (Tab. 5). Other correlations with the horizontal distance were also weak in the Mantel tests and were weakened even further in the partial Mantel tests. The partial correlation between vegetation, spring water and catchment matrices remained - albeit lower - similar to the correlation without horizontal distance. Hence, horizontal geographical distance contained either no or little information on missing spatial variables.

In contrast, there were strong correlations between vegetation $\left(r_{\mathrm{M}}=0.50\right)$, spring water $\left(r_{\mathrm{M}}=0.62\right)$ and catchment $\left(r_{\mathrm{M}}=0.50\right)$ matrices and the vertical geographical distance (Tab. 6). When controlled for the effects of the other variables, the correlation between the vertical distance and the water chemistry remained high $\left(r_{\mathrm{pM}}=0.45\right.$, $)$ while the partial Mantel correlation between the catchment parameters and the water chemistry decreased from $r_{\mathrm{M}}=0.41$ to $r_{\mathrm{pM}}=0.05$. Obviously, the vertical geographical distance, or intelligibly the 
altitude of the spring, can serve as a proxy of unmeasured parameters that have a strong influence particularly on water chemistry, while the correlation between the catchment matrix and the spring water matrix was to a large extent a spurious correlation.

Tab. 5. Results (Pearson correlation) of Mantel tests ( $r_{\mathrm{M}}$, above diagonal) and partial Mantel tests $\left(r_{\mathrm{pM}}\right.$, below diagonal) between vegetation (VEG), spring water chemistry $\left(\mathrm{H}_{2} \mathrm{O}\right)$, catchment traits $(\mathrm{CATCH})$ and horizontal geographical distance (hDIST). All correlations are significant $(p<0.001)$.

\begin{tabular}{lcccc}
\hline & VEG & $\mathrm{H}_{2} \mathrm{O}$ & CATCH & hDIST \\
\hline \multicolumn{5}{c}{ Mantel test $r_{\mathrm{M}}=$} \\
VEG & \multicolumn{5}{c}{0.54} & 0.47 & 0.14 \\
$\mathrm{H}_{2} \mathrm{O}$ & 0.43 & 0.41 & 0.22 \\
CATCH & 0.32 & 0.19 & 0.14 \\
hDIST & -0.02 & 0.15 & 0.14 \\
& \multicolumn{5}{c}{ partial Mantel test $r_{\mathrm{pM}}=$} \\
\hline
\end{tabular}

Tab. 6. Results (Pearson correlation) of Mantel tests $\left(r_{\mathrm{M}}\right.$, above diagonal) and partial Mantel tests $\left(r_{\mathrm{pM}}\right.$, below diagonal) between vegetation (VEG), spring water chemistry $\left(\mathrm{H}_{2} \mathrm{O}\right)$, catchment traits $(\mathrm{CATCH})$ and vertical geographical distance (vDIST). All correlations are significant $(p<0.001)$.

\begin{tabular}{lcccc}
\hline & VEG & $\mathrm{H}_{2} \mathrm{O}$ & CATCH & vDIST \\
\hline \multicolumn{5}{c}{ Mantel test $r_{\mathrm{M}}=$} \\
VEG & \multicolumn{5}{c}{0.54} & 0.49 & 0.50 \\
$\mathrm{H}_{2} \mathrm{O}$ & 0.32 & 0.41 & 0.62 \\
CATCH & 0.26 & 0.05 & 0.50 \\
vDIST & 0.14 & 0.45 & 0.30 \\
& \multicolumn{5}{c}{ partial Mantel test $r_{\mathrm{pM}}=$} \\
\hline
\end{tabular}

The strong influence of the altitude on spring water chemistry was confirmed by a path analysis for the model sketched in figure 3, where the vertical geographical distance had an influence on the spring water (path $p_{4}$ ) and on the catchment (path $p_{5}$ ) and the catchment also had an influence on the spring water (path $p_{6}$ ). The respective path coefficients are $p_{4}=0.55, p_{5}=0.50$ and $p_{6}=0.13$. The total correlation between the vertical distance and the spring water matrix was $r_{\text {tot }}=0.62$. Only $11 \%$ of this correlation was indirect via the catchment matrix. $68 \%$ of the correlation between the vegetation matrix and the spring water matrix was due to a spurious correlation. $61 \%$ of the variation in the vegetation matrix could not be explained by the model.

\section{DISCUSSION}

\subsection{Spring water as a determinant of species composition}

Mantel tests (Tab. 4) and path analysis (Fig. 2) revealed that plant community composition was best explained by the hydrochemical parameters of the spring waters, and first and foremost by the average values of $\mathrm{pH}, \mathrm{Al}$ and $\mathrm{Mg}$, which determine the distance matrix with the highest correlation. Within the prese- lected hydrochemical parameters, all those, which were found to be highly significant by the NMDS $(p<0.001$; see Tab. 2), were closely related to the acidity gradient. This confirms results of previous studies (Beierkuhnlein 1996; Hájková et al. 2008). High concentrations of Al, accompanied by $\mathrm{Mn}, \mathrm{Cd}$ and a low acid neutralizing capacity, mark the acidic end of this gradient (lowest annual mean $\mathrm{pH}$-value was 3.86), whereas concentrations of $\mathrm{Mg}$, accompanied by $\mathrm{Ca}$, are linked to nearneutral spring waters (highest annual mean $\mathrm{pH}$-value was 7.33). Acidity, expressed in particular by the $\mathrm{pH}-$ value, is influenced by the acidic depositions and the buffering processes in soils and the groundwater of the catchments. Low $\mathrm{pH}$-values correspond to high deposition rates and a low buffering capacity. The latter is the case in the investigation area particularly on granite. Toxic $\mathrm{Al}^{3+}$ is released at $\mathrm{pH}$-values $<4.2$. Toxic $\mathrm{Fe}$ concentrations can not be expected at the measured $\mathrm{pH}$-values in our study. The nutrients $\mathrm{Mg}$ and $\mathrm{Ca}$ are mainly released from the soil at $\mathrm{pH}$-values between 6.2 and 8.6.

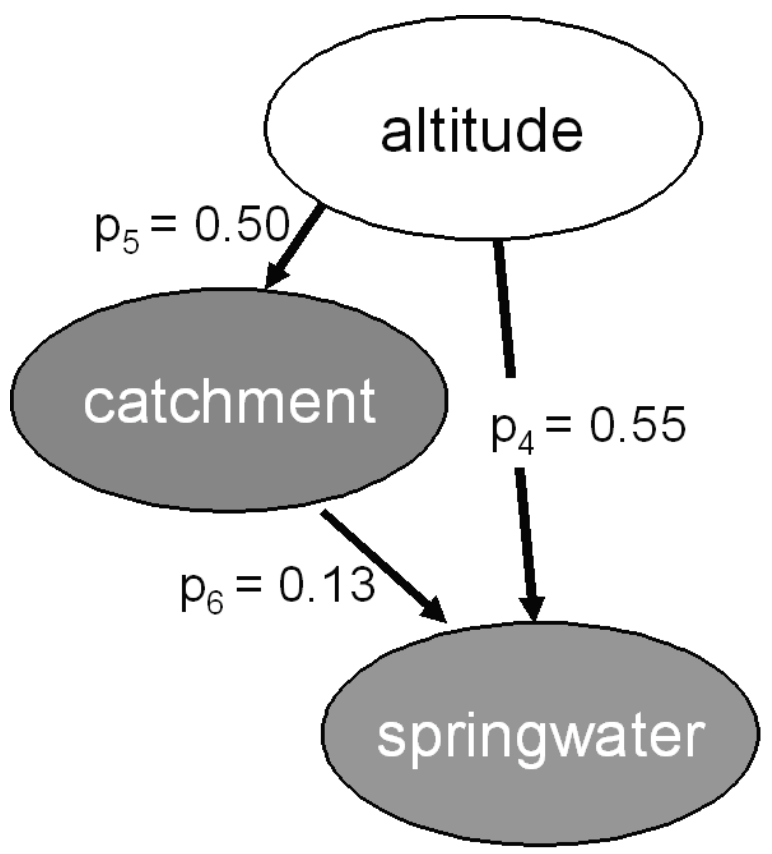

Fig. 3. Presumed relationships between the altitude, the catchment and the spring water. Altitude is used as a representative for spatial factors and processes. The path coefficients were calculated in a path analysis between the distance matrices of the three parameter sets.

It was expected, that out of the minimum, mean and maximum concentrations (over 10 samples from one year) the maximum values of the phytotoxic metals $\mathrm{Al}$, $\mathrm{Mn}$ and $\mathrm{Cd}$ would be crucial, as well as on the other hand the minimum values of the nutrients $\mathrm{Mg}$ and $\mathrm{Ca}$ would be limiting. But surprisingly, in most cases the average values were found to be more significant. Plant species composition responded rather to the year-round hydrochemical characteristics of the spring water, than 
to short-term extreme conditions. This suggests that either the measured fluctuations are too short in duration to become efficient or vegetation is quite resilient towards these seasonal variations. In contrast, Asada (2002) as well as Navrátilová et al. (2006) have found fluctuations of water table depth and hydrochemical parameters to influence vegetation gradients considerably. However, their studies were carried out in fens and other wetland habitats, where environmental factors are known to display larger temporal variation than in springs.

\subsection{The role of the catchment}

Catchment traits play a role in explaining the patterns of our data, but their interpretation is difficult. They did not affect vegetation composition directly, but indirectly via spring water chemistry (Fig. 2). Out of nine catchment parameters that constituted the distance matrix with the highest correlation with plant community composition four are related to the micro- and meso-climate: $1^{\text {st }}$ principal component of the climate parameters, slope, eastward orientation and tree cover. Slope and tree cover as well as the proportional area of deciduous trees can be attributed to light availability as more light reaches spring sites on steeper slopes and in open areas. Springs located under deciduous trees are subject to a strong seasonality of light availability. Trophic conditions are reflected in the bedrock and soil parameters. Finally, most parameters incorporated in the catchment matrix can be construed in terms of acidity. Bedrock and soil parameters reflect the buffering capacity of the catchment. The slope is connected to the residence time of water flowing through the catchment, having an effect on the time available for buffering processes. The factors $1^{\text {st }}$ principal component of the climate parameters, slope, eastward orientation and proportional area of deciduous trees determine the deposition of acidifying compounds. Summing up, catchment traits characterize a complex, interconnected system that is difficult to unravel with field studies.

Surprisingly, the explanatory power of the delineated catchment parameters for the spring water chemistry almost disappeared, when taking spatial relations into account. The vertical geographical distance, solely calculated from the altitude a.s.l., could explain the spring water matrix better (Fig. 3, Tab. 6) than the entirety of catchment parameters. In contrast, integrating horizontal geographical distance into the calculations as a wild card for non-measured landscape characteristics revealed little evidence of the missing variables.

There are four potential ways to interpret the results, differing in their evidentiary value - which will be discussed in the following. (1) There is no relationship between catchment parameters and the water chemistry that drives the vegetation of springs. (2) There is a relationship between catchment parameters and the water chemistry that drives the vegetation of springs, but the parameters that were derived did not cover them. (3) There is a relationship between catchment parameters and the water chemistry that drives the vegetation of springs, but they all depend on the altitude. Therefore altitude might represent biogeochemical processes in the catchment, acting as a sum parameter. (4) There is a relationship between catchment parameters and the water chemistry that drives the vegetation of springs, but acidification has superimposed most differences between the catchments.

Point (1) is highly unrealistic considering all the facts we know about the interrelations between catchment traits and headwater chemistry, both on the global and regional scale (e.g., Reuss et al. 1987; Beierkuhnlein \& Durka 1993; Moldan \& Černý 1994; Church 1997; Likens \& Bormann 1999; Probst et al. 1999; Matzner 2004; Palmer et al. 2004; Björkvald et al. 2008). Furthermore, the results of our Mantel and partial Mantel tests (Tabs 4, 5 and 6) give clear evidence that catchment traits and spring water chemistry are interrelated.

Therefore, point (2) seems to be somewhat more realistic, especially if one takes into account possible errors, such as spatial uncertainties of the spring locations themselves and of the DEM, a difference between the aboveground delimitation and the belowground boundaries of the catchment and the fact that primarily almost all catchment data were not collected for our research objective (cf. Tab. 1). However, connections between catchment traits and spring water chemistry have been shown several times (Probst et al. 1999; Nebe \& Abiy 2002; Hájková \& Hajek 2007). Nebe \& Abiy as well as Hájková \& Hajek related patterns in spring water chemistry to altitude, which leads us to point (3), as most relevant catchment traits that are investigated in our study are correlated with the altitude. The bedrock material found in the highest localities is usually granite, which influences soil formation and buffering capacity. Hence, bedrock material is directly related to the soil type. Furthermore, soil depth declines with increasing altitude. Likewise, climatic parameters are highly predetermined by altitude. In contrast to the air temperature the total amount of precipitation increases with altitude, in particular the amount of precipitation falling as fog and snow. Hence it may be a general fact that $\mathrm{pH}$ and conductivity decrease with increasing altitude even on the same bedrock (cf. Hájková \& Hájek 2007).

We assume that altitudinal differences in the air temperatures do not alter the vegetation growing in the saturated area of the springs, as crenobiotic species benefit from balanced temperatures of the steadily flowing spring water (Odum 1971; Ellenberg 1996). Therefore also winter ice-up is a rare phenomenon. But, the latter might influence the vegetation on larger altitudinal gradients. However, climatic conditions also account for the forest type in the catchments, and this 
includes both natural conditions as well as forestry. With altitude, the stand density becomes lower, whereas the proportion of conifers (mainly Picea abies [L.] H. Karst.) increases at the expense of deciduous trees (mainly Fagus sylvatica L.). Conifer litter is known to contribute to the acidification of soils and groundwater. As a matter of course, horizontal patterns of bedrock, climate (caused by slope and orientaion) and forest types occur. As our results show, these cannot be clearly attributed to the horizontal geographical position or to catchment traits, because they are superimposed by altitudinal issues.

Due to the fact that bedrock, climate parameters and forest vegetation - meaning all three main compartments influenced by altitude - are linked to the process of acidification, we presume that acidic atmospheric depositions are likely to be the "unmeasured parameter" that connects catchment traits with spring water and makes up the correlation with altitude. This underpins point (4). The acidification of soils is a natural process in the studied area but it has been accelerated by anthropogenic emissions since the industrial revolution. Unfortunately, there is neither knowledge on spring water chemistry nor on the plant community for the area that dates back any longer than 20 years. Findings for the Vosges Mountains by Probst et al. (1999) have shown that the $\mathrm{pH}$-value and the alkalinity of springs have declined since the $60 \mathrm{~s}$. Springs in poorly buffered catchments (siliceous sandstone and conglomerate) particularly started to become acidified in the 1970s while springs in catchments with a higher buffering capacity (clay enriched sandstone) became acidified in the 1980s and 1990s. Similar trends can be expected for our study area. To verify the impact of acidification on spring water and vegetation, it would be necessary to include the factor depositions in our analyses, but deposition data are only available for three single locations in our study area and therefore there is a lack of spatiallydetailed, catchment-specific information.

\section{CONCLUSIONS}

Our study supports the hypothesis that the plant species composition of the water saturated area of forest springs in siliceous landscapes is essentially determined by spring water chemistry, and more precisely by an acidity gradient that is reflected mainly by $\mathrm{pH}$-value, $\mathrm{Al}-$ and Mg-concentrations. Catchment traits execute a minor influence on the vegetation of springs, but they are part of the functional chain. This chain is probably driven by the atmospheric depositions that had a strong impact on Central European forested catchments over recent decades and were most effective on siliceous bedrock with a poor buffering capacity. The acidification of ground and surface waters reflects this circumstance. Since the vegetation of springs represents the acidity status of the seeping groundwater, we propose using the plant species composition as an indicator sys- tem for spring water acidity. Indeed the spatial patterns that emerge from spring vegetation can provide valuable ecological information for both hydrologists and foresters.

\section{ACKNOWLEDGEMENTS}

This project was funded in parts by the Bavarian State Ministry of Agriculture and Forestry (board of trustees of the Bavarian State Institute of Forestry LWF, grant L 53) and by the German Federal Ministry of Education and Research (BMBF, grant 0339476 D). The authors would also like to thank the Bavarian state forest administration for the provision of unpublished data and for their cooperation in the field, as well as the Bavarian Office for Surveying and Geographic Information and the Bavarian Environment Agency for the provision of digital topographic and geological maps. Many thanks to Eduard Hertel for identifying some difficult bryophyte species. Thanks also to two anonymous referees for their comments.

\section{REFERENCES}

Alewell, C., M. Armbruster, J. Bittersohl, C.D. Evans, H. Meesenburg, K. Moritz \& A. Prechtel. 2001. Are there signs of acidification reversal in freshwaters of the low mountain ranges in Germany? Hydrol. Earth Syst. Sc., 5: 367-378.

Asada, T. 2002. Vegetation gradients in relation to temporal fluctuation of environmental factors in Bekanbeushi peatland, Hokkaido, Japan. Ecol. Res., 17: 505-518.

Beierkuhnlein, C. 1996. Biomonitoring mit Quellen der silikatischen Mittelgebirge. Crunoecia, 5: 141-151.

Beierkuhnlein, C. \& W. Durka. 1993. Beurteilung von Stoffausträgen immissionsbelasteter Waldökosysteme Nordostbayerns durch Quellwasseranalysen. Forstwiss. Centralbl., 112: 225-239.

Beierkuhnlein, C. \& W. Gräsle. 1998. The influence of light regime and water chemistry on the structure of forest spring vegetation. In: Botosaneanu L. (Ed.), Studies in crenobiology: the biology of springs and springbrooks. Backhuys, Leiden: 9-22.

Björkvald, L., I. Buffam, H. Laudon \& C.-M. Mörth. 2008. Hydrogeochemistry of $\mathrm{Fe}$ and $\mathrm{Mn}$ in small boreal streams: The role of seasonality, landscape type and scale. Geochim. Cosmochim. Ac., 72: 2789-2804.

Cantonati, M., R. Gerecke, E. Bertuzzi. 2006. Springs of the Alps - Sensitive Ecosystems to Environmental Change: From Biodiversity Assessments to Long-term Studies. Hydrobiologia, 562: 59-96.

Church, M.R. 1997. Hydrochemistry of Forested Catchments. Annu. Rev. Earth Pl. Sc., 25: 23-59.

Clarke, K.R. \& M. Ainsworth. 1993. A method of linking multivariate community structure to environmental variables. Marine Ecology Progress Series, 92: 205-219.

Ellenberg, H. 1996. Vegetation Mitteleuropas mit den Alpen in ökologischer, dynamischer und historischer Sicht. 5. Ulmer, Stuttgart: 1095 pp.

Goslee, S. \& D. Urban. 2007. ecodist: Dissimilarity-based functions for ecological analysis. R package version 1.1.3. (http://cran.r-project.org/web/packages/ecodist), accessed October 2007.

Hájek, M., P. Hekera \& P. Hájková. 2002. Spring fen vegetation and water chemistry in the Western Carpathian flysch zone. Folia Geobot., 37: 205-224. 
Hájková, P. \& M. Hájek. 2007. Sphagnum distribution patterns along environmental gradients in Bulgaria. J. Bryol., 29: $18-26$.

Hájková, P., M. Hájek, I. Apostolova, D. Zelený \& D. Dítě. 2008. Shifts in the ecological behaviour of plant species between two distant regions: evidence from the base richness gradient in mires. J. Biogeogr., 35: 282-294.

Heino, J., R. Virtanen, K.-M. Vuori, J. Saastamoinen, A. Ohtonen \& T. Muotka. 2005. Spring bryophytes in forested landscapes: Land use effects on bryophyte species richness, community structure and persistence. Biol. Conserv., 124: 539-545.

Hinterlang, D. 1992. Vegetationsökologie der Weichwassergesellschaften zentraleuropäischer Mittelgebirge. Crunoecia, 1: 5-117.

Kleber, A., J. Lindemann, A. Schellenberger, C. Beierkuhnlein, M. Kaupenjohann \& S. Peiffer. 1998. Slope deposits and water paths in a spring catchment, Frankenwald, Bavaria, Germany. Nutr. Cycl. Agroecosys., 50: 119-126.

Leduc, A., P. Drapeau, Y. Bergeron \& P. Legendre. 1992. Study of spatial components of forest cover using partial Mantel tests and path analysis. J. Veg. Sci., 3: 69-78.

Legendre, P. \& E.D. Gallagher. 2001. Ecologically meaningful transformations for ordination of species data. Oecologia, 129: 271-280.

Legendre, P. \& L. Legendre. 1998. Numerical Ecology. 2. Elsevier, Amsterdam: 853 pp.

Likens, G.E. \& F.H. Bormann. 1999. Biogeochemistry of a Forested Ecosystem. 2. Springer, New York: 159 pp.

Mantel, N. 1967. The detection of disease clustering and a generalised regression approach. Cancer Res., 27: 209-220.

Matzner, E. (Ed.). 2004. Biogeochemistry of Forested Catchments in a Changing Environment. Ecological Studies 172, Springer, Berlin: 498 pp.

Moldan, B. \& J. Černý (Eds). 1994. Biogeochemistry of small catchments - A tool for environmental research. Scope 51, Wiley, New York: 432 pp.

Nantel, P. \& P. Neumann. 1992. Ecology of EctomycorrhizalBasidiomycete Communities on a Local Vegetation Gradient. Ecology, 73: 99-117.

Navrátilová, J., J. Navrátil \& M. Hájek. 2006. Relationships between environmental factors and vegetation in nutrientenriched fens at fishpond margins. Folia Geobot., 41: 353-376.

Nebe, W. \& M. Abiy. 2002. Springwater chemistry of forested water catchment areas in the Erzgebirge. Forstwiss. Centralbl., 121: 1-14.

Received: January 2009

Accepted: June 2009
Nekola, J.C. 2004. Vascular plant compositional gradients within and between Iowa fens. J. Veg. Sci., 15: 771-780.

Odum, E.P. 1971. Fundamentals of Ecology. 3. Saunders, Philadelphia: 574 pp

Oksanen, J., R. Kindt, P. Legendre, B. O'Hara \& M.H.H. Stevens. 2007. vegan: Community Ecology Package. R package version 1.8-8. (http://r-forge.r-project.org/projects/ vegan), accessed October 2007.

Palmer, S.M., C.T. Driscoll \& C.E. Johnson. 2004. Long-term trends in soil solution and stream water chemistry at the Hubbard Brook Experimental Forest: relationship with landscape position. Biogeochemistry, 68: 51-70.

Probst, A., J.P. Party, C. Fevrier, E. Dambrine, A.L. Thomas \& J.M. Stussi. 1999. Evidence of springwater acidification in the Vosges mountains (north-east of France): influence of bedrock buffering capacity. Water Air Soil Poll., 114: 395-411.

$\mathrm{R}$ Development Core Team. 2007. R: A language and environment for statistical computing. $\mathrm{R}$ Foundation for Statistical Computing, Vienna, Austria.

Rantakari, M., P. Kortelainen, J. Vuorenmaa, J. Mannio \& M. Forsius. 2004. Finnish Lake Survey: The Role of Catchment Attributes in Determining Nitrogen, Phosphorus, and Organic Carbon Concentrations. Water Air Soil Poll. Focus, 4: 683-699.

Reuss, J.O., B.J. Cosby \& R.F. Wright. 1987. Chemical processes governing soil and water acidification. Nature, 329: 27-32.

Tahvanainen, T. 2004. Water chemistry of mires in relation to the poor-rich vegetation gradient and contrasting geochemical zones of the north-eastern Fennoscandian shield. Folia Geobot., 39: 353-369.

Thienemann, A. 1924. Hydrobiologische Untersuchungen an Quellen. Arch. Hydrobiol., 14: 151-189.

Vitt, D.H. \& W.-L. Chee. 1990. The relationships of vegetation to surface water chemistry and peat chemistry in fens of Alberta, Canada. Vegetatio, 89: 87-106.

Warncke, E. 1980. Spring areas: ecology, vegetation, and comments on similarity coefficients applied to plant communities. Holarctic Ecol., 3: 233-308.

Williard, K.W.J., D.R. Dewalle \& P.J. Edwards. 2005. Influence of bedrock geology and tree species composition on stream nitrate concentrations in mid-Appalachian forested watersheds. Water Air Soil Poll., 160: 55-76. 